\title{
Postcolonial Studies: Hybridity and the Dominance of Whites over Blacks in American Poetry
}

\author{
Yuli Wahyuni ${ }^{1}$, Diyah Iis Andriani ${ }^{2}$
}

${ }^{1,2}$ Universitas Pamulang, Tangerang Selatan, Indonesia

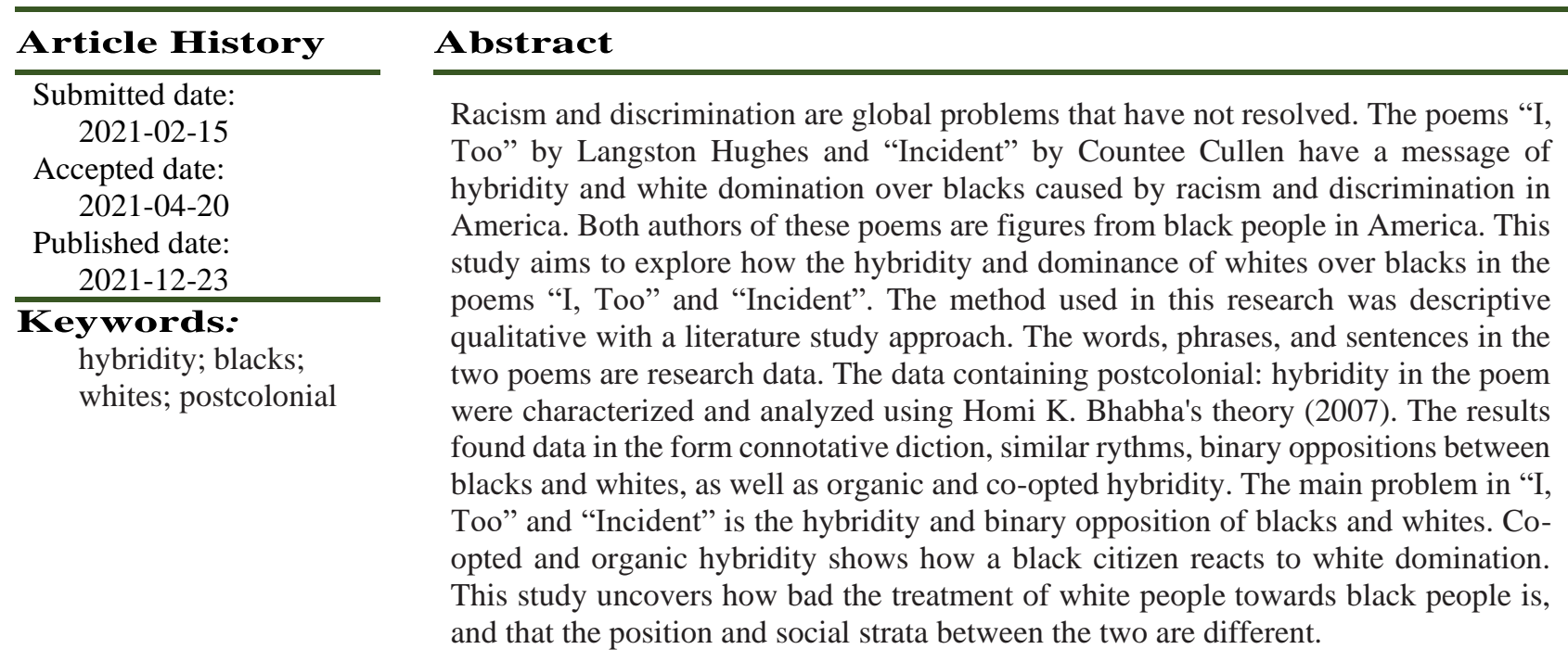

\section{Kata Kunci:}

Hibriditas; kulit hitam; kulit putih; poskolonial

\section{Abstrak}

Kajian Poskolonial: Hibriditas dan Dominasi Kulit Putih atas Kulit Hitam dalam Puisi Amerika

Rasisme dan diskriminasi merupakan masalah dunia yang hingga saat ini masih belum bisa teratasi. Puisi "I, Too" karya Langston Hughes dan "Incident" karya Countee Cullen memiliki pesan hibriditas dan dominasi kulit putih atas kulit hitam yang disebabkan karena rasisme dan diskriminasi yang terjadi di Amerika. Kedua pengarang puisi tersebut merupakan tokoh dari kaum kulit hitam di Amerika. Penelitian ini bertujuan mengeksplorasi bagaimana hibriditas dan dominasi kulit putih atas kulit hitam di dalam puisi "I, Too" dan "Incident". Metode yang digunakan dalam penelitian ini adalah kualitatif deskriptif dengan pendekatan studi pustaka. Kata, frasa, dan kalimat dalam kedua puisi tersebut merupakan data penelitian. Data yang mengandung poskolonial: hibriditas dalam puisi tersebut ditandai dan dianalisis menggunakan teori Homi K. Bhabha (2007). Hasilnya ditemukan data berupa diksi bermakna konotatif, persamaan bunyi, oposisi biner antara kulit hitam dan kulit putih, serta hibriditas organik dan terkooptasi. Permasalahan utama pada puisi "I, Too" dan "Incident" adalah hibriditas dan oposisi biner kulit hitam dan kulit putih. Hibriditas terkooptasi dan organik memperlihatkan bagaimana seorang warga kulit hitam bersikap terhadap dominasi masyarakat kulit putih. Penelitian ini membongkar bagaimana buruknya perlakuan masyarakat kulit putih terhadap masyarakat kulit hitam, serta bahwa kedudukan dan strata sosial antara keduanya berbeda.

Corresponding author:

${ }^{1}$ englishliterature.yuli@gmail.com 


\section{Pendahuluan}

Rasisme dan diskriminasi merupakan masalah dunia yang sampai saat ini masih belum bisa teratasi. Rasisme dan diskriminasi biasanya menyangkut antara kulit hitam dan kulit putih. Isu tersebut sudah dimulai sejak periode tahun 1920-an di Amerika Serikat ketika masyarakat kulit hitam hanya dijadikan budak pekerja oleh masyarakat kulit putih alih-alih dijadikan sebagai seorang saudara. Masyarakat kulit hitam diberdayakan untuk mengurus pekerjaan kasar di perkebunan, pertambangan, perindustrian, dan lini usaha lainnya. Pada umumnya, masyarakat kulit hitam hanya dimanfaatkan untuk pekerjaan berat dan kasar. Pada tatanan sosial mereka juga berada di kelas kedua. Kelas pertama didominasi oleh masyarakat kulit putih dengan fasilitas yang utama dan terbaik. Selain itu, hal ini dapat terlihat dari peristiwa yang muncul berdasarkan berita dari Aljzeera pada tanggal 30 Desember 2020. Peristiwa tersebut adalah terbunuhnya seorang warga kulit hitam bernama George Floyd oleh seorang polisi kulit putih di Amerika. Terbunuhnya George Floyd tidak hanya karena tindakan kekerasan tetapi juga intimidasi dan rasisme. Hal ini memunculkan gerakan protes besarbesaran di beberapa kota besar di Amerika Serikat. Gerakan massa semakin lama semakin membesar dan memunculkan situasi yang tidak terkendali. Kerusuhan, keributan, dan adu fisik antara polisi dan pendemo tidak terhindarkan. Selanjutnya, gerakan protes meluas hingga memunculkan tagar Black Lives Matter (Aljazeera, 2020).

Gerakan Black Lives Matter (BLM) sebenarnya terbentuk pada tahun 2013 dengan tujuan menanggapi pembebasan pembunuh Travyon Martin. BLM selanjutnya bertujuan memperjuangkan hak-hak masyarakat kulit hitam atas dominasi masyarakat kulit putih yang sering merugikan masyarakat kulit hitam. Slogan yang dikumandangkan BLM dalam laman resminya adalah memberantas supremasi masyarakat kulit putih atas masyarakat kulit hitam dan membangun kekuatan lokal untuk melawan intimidasi dan kekerasan dari masyarakat kulit putih. BLM menunjukkan pada dunia bahwa Gerakan Hak Sipil sekitar tahun 1960-an masih belum tuntas. Masih banyak pelanggaran dan kekerasan yang dilakukan masyarakat kulit putih atas masyarakat kulit hitam di Amerika Serikat (Black Lives Matter, 2021).

Sungguh miris masih terjadinya peristiwa rasisme di negara yang menyerukan kebebasan dan kesetaraan. Padahal, di negara Amerika Serikat sudah banyak masyarakat kulit hitam mengambil peran strategis di lingkup sosial seperti artis, politisi, musisi, penyanyi, pengacara, pengusaha, dan puncaknya seorang Barack Obama menjadi presiden kulit hitam pertama. Sungguh ironis, dibalik gemerlapnya kehidupan sosial di Amerika ternyata menyimpan sebuah kenyataan yang memprihatinkan. Aksi besar-besaran dalam upaya membela ketidakadilan dan kekerasan tehadap masyarakat kulit hitam menjadi bukti bahwa rasisme masih berkembang dikehidupan nyata masyarakat Amerika Serikat.

Kejadian-kejadian mengandung isu postkolinialisme tersebut diceritakan secara tersirat maupun tersurat dalam karya sastra ciptaaan manusia. Oleh karena itu, penulis tertarik untuk menganalisis wacana postkolinialisme yang terdapat di dalam karya sastra puisi. Selain itu, alasan dipilihnya karya sastra puisi adalah karena puisi singkat tulisannya, tetapi kaya akan makna yang terkandung didalamnya (Kosasih, 2008). Puisi adalah salah satu karya sastra yang cukup rumit karena butuh daya nalar dan imajinasi yang tinggi. Saat ini sudah banyak teori yang membahas puisi. Secara etimologi, istilah puisi berasal dari bahasa Yunani poeima yang berarti membuat atau pembuatan. Puisi dimaknai sebagai membuat atau pembuatan dikarenakan pada dasarnya manusia telah menciptakan suatu dunia tersendiri yang mungkin berisi gambaran atau pesan tertentu baik secara fisik atau batin (Aminuddin, 2004).

Puisi juga merupakan bentuk karya sastra yang tersaji secara monolog dengan menggunakan kata-kata indah dan kaya akan makna. Kekayaan akan makna disebabkan adanya unsur kepadatan 
segala unsur bahasa. Adapun penggunaan bahasanya bukanlah bahasa percakapan sehari-hari atau bahasa karya sastra tulis lainnya yang menggunakan kalimat yang panjang dan detil. Puisi menggunakan bahasa yang ringkas tetapi penuh makna karena kata-katanya bersifat konotatif yang mengandung banyak penafsiran dan pengertian (Kosasih, 2008). Puisi adalah ucapan atau ekspresi tidak langsung (Pradopo, 2007). Puisi juga merupakan ucapan ke inti peristiwa, masalah atau narasi (Suswandari \& Hatmo, 2018). Pada intinya, puisi merupakan karya sastra dengan penggunaan kata singkat, padat, penuh keindahan, dan kaya akan makna. Berdasarkan pengertian puisi di atas, sifat yang terpenting puisi adalah puitis. Sesuatu yang disebut puitis adalah sesuatu hal yang membangkitkan perasaan, menarik perhatian, dan menimbulkan tanggapan yang jelas. Puitis bukanlah sebuah referensi tetapi pemakaian bahasa itu sendiri yang menjadi pusat perhatian meskipun fungsi-fungsi lain bukan tidak ada dalam puisi (Teeuw, 2010). Kata-kata puitis sering kali disebut ketika seseorang mendengar untaian kata-kata indah dalam puisi. Secara sederhana, puitis merupakan kata-kata indah yang singkat yang ditujukan mengungkapkan suatu makna yang luas menjadi pemahaman yang luar biasa hanya dalam beberapa kata.

Dalam menganalisa puisi dibutuhkan pengetahuan tentang puisi itu sendiri. Hal pertama yang dibutuhkan dalam menganalisis puisi adalah cara mengidentifikasi klasifikasi puisi tersebut. Puisi banyak klasifikasinya seperti puisi epik, dramatik, didaktik, satirik dan lainnya. Kalsifikasi puisi ini bertujuan agar analisis suatu puisi menjadi lebih fokus terhadap isi dan mendekati makna konotatif yang terkandung didalamnya. Tidak mudah menentukan klasifikasi suatu puisi tetapi juga bukanlah hal yang sulit untuk ditentukan. Hal sulit dalam menentukan klasifikasinya adalah makna konotatif di dalamnya. Kata-kata yang mengandung makna konotatif tidak bisa secara langsung diketahui tema, bentuk imajinasinya, dan makna tersurat maupun tersirat. Dibutuhkan daya imajinasi yang kuat agar bisa menentukan klasifikasinya. Ini berarti bahwa daya imajinasi yang kuat merupakan komponen yang penting baik dari pihak penulis maupun pembaca.

Karya sastra puisi yang diteliti dalam penelitian ini adalah "I, Too" karya Langston Hughes dan "Incident" karya Countee Cullen. Puisi "I, Too" dan "Incident" merupakan karya tokoh kulit hitam di Amerika Serikat. Puisi "I, Too" ini pertama kali diterbitkan pada Maret 1925 dalam edisi khusus majalah Survey Graphic berjudul Harlem: Mecca of the New Negro kemudian dicetak ulang dalam volume pertama puisi Hughes, The Weary Blues pada tahun 1926. Sedangkan, puisi "Incident" merupakan salah satu puisi karya Countee Cullen yang pertama dan paling terkenal dalam koleksi puisi Color yang terbit pada tahun 1925 .

Alasan kuat lainnya dipilihnya puisi "I, Too" dan "Incident" dalam penelitian ini adalah karena terdapat isu poskolonial pada kedua puisi tersebut. Hal utama yang melandasi penulis mengambil kajian poskolonial karena di dalam puisi "I, Too" dan "Incident" terdapat bentuk kolonialisme baru. Bentuk kolonialisme baru yaitu adanya bentuk penindasan, rasisme, dan hibriditas (Martono, 2014). Penindasan tidak hanya berupa kekerasan fisik saja tapi bisa juga dalam bentuk verbal. Kata-kata yang merendahkan derajat seseorang terkait ras, agama, dan budaya merupakan salah satu bentuk kolonialisme baru. Puisi "I, Too" dan "Incident" bukanlah karya pengungkapan bentuk rendah diri, namun sebuah keputusasaan dari masyarakat kulit hitam karena terdapat bentuk perlawanan dari masyarakat kulit hitam. Bentuk perlawanan tersebut dijabarkan berdasarkan teori hibriditas dari Homi K. Bhabha (Bhabha, 2007).

Menurut penulis, teori Homi K. Bhabha (2007) tentang hibriditas merupakan teori yang sesuai dijadikan teori utama dalam menganalisa puisi "I, Too" dan "Incident" . Menurut Bhabha dalam Syuropati (2012), konsep hibriditas digunakan untuk menggambarkan bergabungnya dua bentuk yang memunculkan sifat-sifat tertentu dari tiap-tiap bentuk, dan sekaligus meniadakan sifat-sifat tertentu yang dimiliki keduanya (Syuropati, 2012). Teori hibriditas Bhabha berawal dari pemikiran 
Jacques Derrida, Foucault, dan Freud bahwa secara psikologis ada kebanggan bagi penjajah ketika menaklukkan wilayah jajahannya. Sedangkan teori poskolonial Bhabha dipengaruhi oleh Edward Said dan Franz Fanon. Baik Edward Said dan Franz Fanon lebih banyak mengulas wacana "penjajah" dan "terjajah" yang merupakan oposisi biner.

Bhabha dalam pemikirannya berusaha memberikan "ruang tengah" antara "penjajah" dan "terjajah" (Bhabha, 2007). Konsep adanya "ruang tengah" disebut Bhabha sebagai time-lag, yaitu struktur keterbelahan (ambivalensi) dari wacana kolonial yang menjadikan subjek selalu berada pada the liminal space between culture. Hal ini bisa diartikan yaitu pada saat demarkasi strukturnya kaku, tidak tetap dan tidak dapat diketahui batas ujungnya (Brown, 2011). Konsep liminalitas (liminal space) Bhabha mendeskripsikan "ruang tengah" atau "ruang antara" tempat perubahan budaya dapat berlangsung. Ruang tersebut adalah ruang antarbudaya tempat strategi-strategi kedirian personal (akumulasi dari struktur subjek) atau komunal dapat dikembangkan. Hal itu dapat dilihat pula sebagai suatu wilayah proses gerak dan pertukaran antara status yang berbeda-beda dan yang terus-menerus. Semua ungkapan dan sistem budaya tersebut dibangun dalam sebuah ruang yang disebut "ruang enusiasi ketiga" (Bhabha, 2007).

Hibriditas dari Homi K. Bhabha banyak dijadikan acuan dalam menganalisis suatu karya sastra. Salah satu contohnya analisis hibriditas Homi K. Bhabha dalam novel Midnight's Children karya Salman Rushdie yang disusun oleh Syihabul Furqon dan Busro dari UIN Sunan Gunung Jati Bandung 2020 (Furqon, S., \& Busro 2020). Dalam penelitian tersebut mereka menganalisis sebuah novel yang memiliki penceritaan di India pada masa awal kemerdekaan. Diceritakan seorang anak bernama Saleem yang memiliki kehidupan yang cukup berada jika dibandingkan dengan anak-anak lainnya di India. Pada masa itu diceritakan India mengalami sebuah pergolakan di dalam negeri pasca berakhirnya kolonialisme Inggris. India mengalami perpecahan antara penganut Hindu dan Islam sehingga melahirkan dua negara, yaitu India dan Pakistan. Perjalanan hidup Saleem dari keluarga kaya hingga jatuh miskin dan selanjutnya menikahi wanita Hindu pinggiran yang diperkosa serdadu Inggris menjadikan Saleem mengalami kondisi multikulturalisme. Pada akhir cerita, keturunan dari Saleem dan Parvati seperti kehilangan identitas budaya karena terjadi percampuran antara masyarakat Hindu, Islam dan Barat. Hasil penelitian tersebut menyatakan bahwa percampuran tersebut menghasilkan suatu bentuk baru dan tidaklah sepenuhnya sama dengan yang lainnya. Disadari maupun tidak, hibriditas akan melahirkan mimikri pada perkembangan selanjutnya.

Penelitian lain yang bisa dijadikan acuan hibriditas Homi K. Bhabha adalah Mimikri dalam Puisi "Hari itu Aku akan Bersiul-siul" Karya Wiji Thukul (kajian poskolonial) karya Olivia dan Salim (2020) dari Universitas Sebelas Maret yang dimuat pada Oktober 2020. Penelitian ini menggunakan puisi sebagai objek utama penelitian. Teori utama yang digunakan adalah kajian poskolonial dari Homi K. Bhabha. Penelitian tersebut mengungkapkan mimikri yang terdapat pada puisi karya Wiji Thukul yang mana bertujuan sebagai bentuk perlawanan terhadap pemerintahan Orde Baru (Olivia, H. M., \& Salim, 2020). Seperti puisi "I, Too" karya Langston Hughes dan "Incident" karya Countee Cullen di Amerika Serikat, puisi "Hari Itu Aku akan Bersiul-siul" karya Wiji Thukul memiliki persamaan yaitu melawan kesewenangan penguasa melalui jalur puisi. Puisi karya Wiji Thukul tersebut menceritakan kondisi Pemilihan Umum (pemilu) Presiden yang terjadi pada tahun 1997 di Indonesia yang saat itu dikuasai Orde Baru. Kondisi pemilu saat itu jauh dari kata jujur dan adil bahkan seperti "sudah diatur" siapa yang akan jadi pemenangya. Kecurangan yang paling disorot pada puisi tersebut adalah pemberian sembako kepada pemilik suara untuk memenangkan pihak tertentu. Oleh karena itu, "si aku" pada puisi tersebut mengolok-olok pemilu dengan kata "pilu", pemilu hanya penambah isi dapur, dan "si aku" tidak akan memberikan pilihan suara dan hanya akan bersiul-siul saja pada saat pemilu berlangsung. 
Bagaimanapun juga, dibandingkan dengan penelitian sebelumnya, pada penelitian ini penulis menganalisis puisi Amerika puisi "I, Too" dan "Incident" yang bertujuan untuk mengungkapkan masih adanya kesenjangan sosial yang terjadi di Amerika Serikat yang disebut-sebut sebagai negara demokrasi liberal yang menggaungkan kebebasan dan kesetaraan. Puisi "I, Too" dan "Incident" merupakan salah satu contoh perlawanan yang elegan dari pihak tertindas yang menggunakan ranah sastra. Setiap individu yang lahir dan hidup pada setiap negara berhak mendapat pengakuan dari seluruh warga negara tanpa membedakan ras dan etnis untuk hidup penuh kedamaian. Oleh karena itu, penelitian ini ditujukan untuk menjawab persoalan tentang bagaimana unsur-unsur dan bentuk hibriditas pada puisi "I, Too" karya Langston Hughes dan "Incident" karya Countee Cullen yang dianalisa menggunakan teori Homi K. Bhabha (2007)

\section{Metode}

Dalam penelitian ini, penulis menggunakan metode deskriptif kualitatif. Penelitian deskriptif kualitatif adalah metode penelitian yang memanfaatkan data kualitatif yang kemudian dijabarkan dengan deskriptif. Penelitian kualitatif mengutamakan pendalaman dan penghayatan terhadap interaksi antar konsep yang sedang dikaji secara empiris (Semi, 2010). Sebagaimana yang dikemukakan oleh Semiawan (2010) bahwa hasil penelitian kualitatif sangat dipengaruhi oleh pandangan, pemikiran, dan pengetahuan peneliti (Semiawan, 2010). Selain itu, Siswantoro dalam Jumiati (2016) menyatakan bahwa prosedur dalam penelitian deskriptif pemecahan masalah diselidiki dengan menggambarkan keadaan subjek atau objek penelitian pada saat ini berdasarkan fakta yang ada (Jumiati, 2016). Sedangkan menurut Sendari (2019), kualitatif adalah penelitian yang bersifat deskriptif dan menggunakan analisis untuk mengetahui proses dan makna dari objek yang diteliti (Sendari, 2019). Penelitian ini bertujuan untuk mendeskripsikan bagaimana hibriditas dan dominasi kulit putih atas kulit hitam yang digambarkan dalam puisi "I, Too" dan "Incident" .

Data dalam penelitian ini adalah kata-kata, frasa, dan kalimat yang terdapat di dalam kedua puisi tersebut. Dalam penelitian ini, penulis melakukan beberapa langkah pengumpulan data dengan menggunakan pendekatan studi pustaka. Pendekatan studi pustaka (library research) merupakan satu teknik pengumpulan data dan sumber penelitian melalui buku, jurnal, majalah, surat kabar dan lainlain (Nazir, 1988). Adapun langkah pertama adalah membaca puisi-puisi tersebut beserta teori-teori yang relevan. Puisi-puisi tersebut dibaca beberapa kali guna mendapatkan pemahaman mendalam terkait isu dan permasalahan yang terdapat dalam puisi-puisi, yang berupa teori unsur puisi seperti unsur fisik dan batin (Suswandari, \& Hatmo, 2018). Tahap kedua, memilih kalimat-kalimat yang mengandung isu poskolonial yang kemudian ditandai untuk dianalisis menggunakan teori hibriditas (Bhabha, 2007). Tahap berikutnya adalah tahap pengujian data. Di tahap ini, kalimat-kalimat tersebut dievaluasi dan dihubungkan dengan teori-teori poskolonial seperti hibriditas organik yang memberikan perlawanan dan terkooptasi yang toleran (Bhabha, 2007).

\section{Hasil dan Pembahasan}

Hasil penelitian unsur puisi "I, Too" dan "Incident" disajikan dalam bentuk ulasan berdasarkan teori puisi seperti analisis unsur dan klasifikasi puisi. Selanjutnya, puisi "I, Too" dan "Incident" dianalisis berdasarkan teori sastra yaitu poskolonial dengan rujukan utama teori hibriditas. Analisis puisi dieksplorasi berdasarkan subjektivitas tokoh "aku" yang dipanggil the darker brother pada puisi "I, Too" dan he poked out His tongue, and called me, "Nigger" pada puisi "“"Incident" " sebagai contohnya. Kemudian, hal itu juga harus selaras dengan teori-teori yang relevan seperti unsur-unsur puisi dan hibriditas organik dan terkooptasi sehingga hasilnya bisa mengungkapkan makna yang terkandung maupun terselebung pada kedua puisi tersebut. 
Wahyuni, Y. \& Iis Andriani, D., (2021). Postcolonial Studies: Hybridity and the Dominance of Whites over Blacks in American Poetry. LITE: Jurnal Bahasa, Sastra, dan Budaya 17 (2), 185-197. https://doi.org/10.33633/ $\underline{\text { lite.v17i2.5058 }}$

Table 1. Hasil

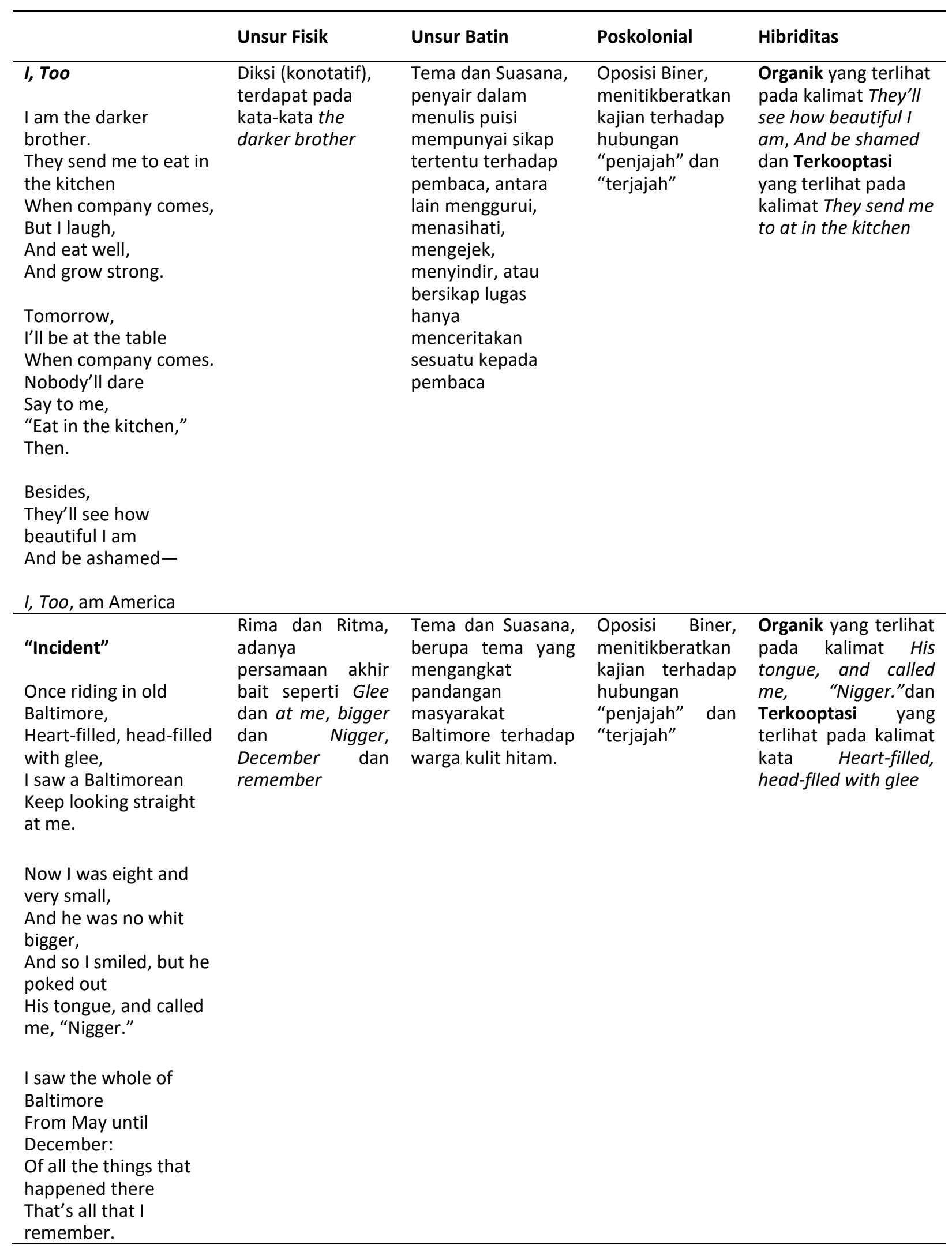




\subsection{Unsur Puisi}

Pada puisi "I, Too" , terdapat unsur fisik dan batin pada puisi tersebut. Unsur fisik terlihat pada penggunaan kata-kata yang konkret dan menggunakan diksi yang konotatif. Untaian kata-kata pada puisi "I, Too" mengalir santai seperti seseorang menceritakan hal yang dialaminya.

\section{I am the darker brother.}

They send me to eat in the kitchen

Kalimat yang berawal dari I am the darker brother menggunakan kata-kata bermakna konotatif maupun penggunaan diksi khusus. I am the darker brother menyatakan "si aku" merupakan seseorang dengan kulit yang gelap. Tidak ada gambaran yang menunjukkan kata-kata darker brother sebuah kata kiasan. Hal ini diperjelas dengan baris kalimat berikutnya They send me to eat in the kitchen yang berarti "mereka menyuruh saya makan ke ruangan dapur." Subjek pada kalimat puisi tersebut adalah $I$ dan they, di mana antara $I$ dan they terjadi sebuah komunikasi mengenai tempat makan. Baris puisi tersebut tidak terlihat adanya kata-kata dengan multitafsir. Tidak terdapat pula kata-kata perandaian seperti "seolah-olah", "bagaikan" atau kata-kata yang menimbulkan banyak makna. Jadi unsur fisik pada puisi "I, Too" adalah penggunaan bahasa konkret dan detail sesuai dengan kondisi "si aku" dalam puisi tersebut.

Selain unsur fisik, ada unsur batin yang terdapat pada puisi "I, Too". Salah satu unsur batin pada puisi adalah tema. Pada puisi "I, Too", tema yang dominan terlihat adalah nada dan suasana. Tema nada dan suasana adalah penyair dalam menulis puisi mempunyai sikap tertentu terhadap pembaca, antara lain menggurui, menasihati, mengejek, menyindir, atau bersikap lugas hanya menceritakan sesuatu kepada pembaca. Pada puisi "I, Too", untaian kata-kata sangat terasa sekali ungkapan "si aku" dalam menceritakan perasaannya.

I am the darker brother.

They send me to eat in the kitchen

But I laugh,

And eat well,

And grow strong.

Pada puisi "I, Too", subjek "si aku" menggambarkan bagaimana kondisi dan suasana yang dirasakan. Subjek "si aku" merasakan adanya percampuran perasaan seperti kesedihan, senang, semangat yang membara, dan ada keinginan untuk membalas dendam. Dari awal kata-kata puisi sudah ada penggambaran bentuk suasana oleh subjek "si aku".

Kata-kata I am the darker brother menggambarkan bagaimana kondisi "si aku" dipertegas dengan kalimat berikutnya:

They send me to eat in the kitchen

But I laugh,

And eat well,

And grow strong 
Subjek "si aku" berada di kondisi dan suasana tidak begitu menguntungkan. Meskipun dia menganggap subjek lain sebagai saudara, tetapi dia tidak dianggap sebagai teman bahkan saudara di mana dia haruskan makan di dapur. Subjek "si aku" tidak merasa tersinggung bahkan tertawa dan ada semangat untuk tetap kuat menjalani kehidupannya.

Selanjutnya, pada puisi "Incident", unsur fisik yang terlihat adalah adanya kesamaan bunyi pada tiap bait. Pengulangan kata-kata disebut juga rima dan ritma.

Once riding in old Baltimore,

Heart-filled, head-filled with glee,

I saw a Baltimorean

Keep looking straight at me.

Pada akhir bait terdapat persamaan bunyi kata seperti -more dan ee yang terlihat pada kata glee dan me. Sedangkan ritma terlihat pada Heart-filled, head-filled with glee. Pada kalimat tersebut terdapat pengulangan kata dengan bunyi seirama. Kata-kata tersebut menciptakan keindahan dan ketegasan dalam pengungkapannya.

Now I was eight and very small,

And he was no whit bigger,

And so I smiled, but he poked out

His tongue, and called me, "Nigger."

I saw the whole of Baltimore

From May until December:

Of all the things that happened there

That's all that I remember.

Semua bait pada puisi "Incident" memiliki pola yang sama, yaitu menggunakan pengulangan bunyi pada akhir baitnya. Pola pengulangan bunyi tersebut memberikan keindahan dan tidak terlihat berlebihan. Susunan kata pada tiap bait menyampaikan kesederhanaan tanpa diksi yang berlebihan dalam menyampaikan rasa seperti ...And so I smiled, but he poked out dan kejujuran dalam mengungkapkan apa yang dilihat, seperti I saw the whole of Baltimore... That's all that I remember. Menariknya, kesederhanaan kata-kata tersebut disampaikan dengan keindahan kata akhir dengan bunyi yang sama sehingga memunculkan keindahan bunyi.

Selanjutnya, unsur batin yang terdapat pada puisi "Incident" berupa tema yang mengangkat pandangan masyarakat Baltimore terhadap warga kulit hitam. Puisi "Incident" menceritakan tokoh "aku" yang sedang berjalan di jalanan Baltimore dengan penuh kegembiraan. Ketika tokoh "aku" berada di keramaian orang-orang di Baltimore, terjadi sesuatu hal yang cukup mengerikan. Tokoh "aku" merasakan tatapan intimidasi dikarenakan perbedaan warna kulit.

Once riding in old Baltimore,

Heart-filled, head-filled with glee, 


\author{
I saw a Baltimorean \\ Keep looking straight at me. \\ Now I was eight and very small, \\ And he was no whit bigger, \\ And so I smiled, but he poked out \\ His tongue, and called me, "Nigger."
}

Tatapan intimidasi terlihat pada untaian kata I saw a Baltimorean, keep looking straight at me. Kata-kata tersebut mendeskripsikan orang-orang Baltimore memandang lurus tajam ke arah tokoh "si aku". Pada umumnya pandangan lurus tajam keseseorang menunjukkan ada sesuatu ketertarikan pada orang tersebut. Pandangan tersebut bisa berupa pandangan positif maupun negatif. Pada puisi "Incident" pandangan orang-orang Baltimore adalah pandangan yang mengandung arti negatif. Hal tersebut diperlihatkan pada kata-kata And so I smiled, but hoe pocked out, His tongue, and called me, "Niger". Tokoh "aku" sudah berusaha memberikan respon positif terhadap pandangan orang-orang Baltimore dengaan memberikan senyuman. Meskipun begitu, tokoh "aku" tidak mendapatkan respon positif dari senyumannya bahkan mendapatkan perlakuan lebih buruk berupa perkataan yang kasar. Hal tersebut terlihat pada kata-kata His tongue, and called me, "Nigger". Kata Nigger diasosiasikan kepada sebuah negara di Afrika dengan tujuan menghina ras kulit hitam.

\subsection{Kajian Poskolonial}

Puisi sebagai salah satu karya sastra juga memiliki pesan yang disampaikan kepada pembaca. Hanya saja, puisi memiliki kerumitan tersendiri dalam mengungkapkan pesan yang akan disampaikan. Puisi tidaklah sama dengan novel yang menggunakan deskripsi detail dalam menyampaikan pesan. Kata-kata singkat yang digunakan seakan-akan merangkum semua perasaan yang akan disampaikan. Hal ini merupakan suatu kerumitan tersendiri untuk menjabarkan pesan yang terdapat dalam suatu puisi.

Pesan yang terdapat dalam puisi tidak hanya dikaji berdasarkan teori puisi seperti unsur dan klasifikasi puisi saja, tetapi bisa juga dikaji menggunakan teori-teori sastra lainnya. Salah satu teori sastra yang bisa digunakan adalah teori poskolonialisme. Teori poskolonialisme menitikberatkan kajian terhadap hubungan "penjajah" dan "terjajah". Ini erat hubungannya dengan kondisi dunia sebelum Perang Dunia Kedua berakhir ketika bangsa Barat melakukan penjajahan dan penguasaan terhadap negara-negara Asia dan Afrika. Bentuk penjajahan oleh bangsa Barat mencakup semua aspek seperti ekonomi, politik, budaya, dan kegamaan.

Setelah Perang Dunia Kedua berakhir penjajahan masih sama dalam arti mencakup semua aspek tetapi bentuk yang berbeda. Perbedaan yang paling mencolok adalah bentuk penjajahan sesudah Perang Dunia Kedua berupa penguasaan jaringan kekayaan alam di suatu negara terjajah tanpa harus menguasai secara fisik. Hal ini dapat diartikan bahwa penjajahan dilakukan dalam bentuk penguasaan aspek-aspek penting suatu negara seperti ekonomi, sumber daya alam, dan kebudayaan. Pada aspek ekonomi, penguasaan dilakukan dalam bentuk monopoli pasar dan bertindak sebagai pemilik modal yang besar demi keuntungan yang sebesar-besarnya.

Di sisi lain, di bidang kebudayaan terjadi persilangan budaya antara "penjajah" dan "terjajah". Budaya yang dibawa oleh "penjajah" akan berkembang di wilayah "terjajah" dan menghasilkan suatu budaya yang berbeda antara satu dan lainnya. Budaya baru yang terjadi setelah adanya interaksi antara dua budaya inilah yang dimaksud hibriditas. Kemudian, hibriditas budaya di wilayah terjajah akan 
mengalami perkembangan ke kondisi perlawanan dengan meniru budaya penjajah oleh terjajah. Hal ini disebut juga dengan mimikri atau peniruan.

Pada puisi "I, Too" dan "Incident", terlihat jelas adanya konsep "penjajah" dan "terjajah" dimana masyarakat kulit putih sebagai bentuk "penjajah" dan masyarakat kulit hitam sebagai "terjajah". Ada beberapa kata dalam puisi yang menegaskan adanya pertentangan atara kulit putih dan kulit hitam.

\section{I am the darker brother.}

They send me to eat in the kitchen

Pada puisi "I, Too", terlihat jelas pertentangan antara kulit putih dan kulit hitam dengan penegasan pada kata-kata I am the darker brother yang berarti si "aku" merupakan saudara "berkulit gelap". Tokoh si "aku" menyadari adanya perlakuan rasis yang terjadi di tempat dia tinggal karena si "aku" dengan sadar mengakui bahwa dia adalah seorang darker brother yang berarti saudara yang berkulit gelap. Kemudian, kata-kata They send me to eat in the kitchen menegaskan tindakan rasisme yang terjadi pada tokoh "aku" dikarenakan si "aku" merupakan seorang warga kulit hitam di mana tidak diperbolehkan makan malam di meja yang sama dengan warga kulit putih. Seorang warga kulit hitam harus makan di dapur ketika tuan rumah yang seorang kulit putih datang. Hal ini tidak hanya sekedar tindakan rasis tetapi berupa perbudakan yang menguasai hidup seseorang. Perbedaan warna kulit dijadikan pembenaran untuk menguasai hidup seseorang. Selanjutnya, pada puisi "Incident" perlakuan rasis atas nama warna kulit juga terlihat jelas. Warna kulit dijadikan penghakiman untuk hidup seseorng meski tidak melakukan suatu tindakan kejahatan.

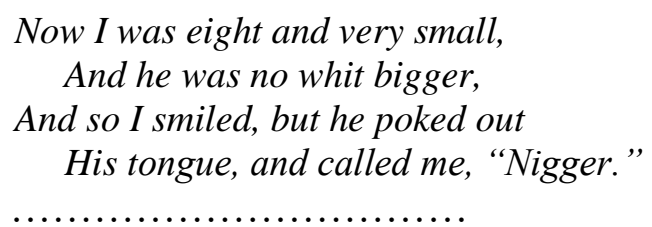

Tindakan rasis pada puisi "Incident" tidak memandang usia. Anak kecil berusia delapan tahun pun tidak luput dari tindakan rasis tersebut. Tokoh "aku" sudah berusaha ramah terhadap seseorang kulit putih dengan tersenyum, tetapi yang dia dapatkan adalah sebuah penghinaan. Hinaan yang ditujukan dengan menyebut sebuah nama masyarakat yang hidup di negara Nigeria di Afrika yaitu Nigger.

\subsection{Kajian Hibriditas}

Hibriditas secara teori poskolonial merupakan terbentuknya budaya baru dari interaksi budaya yang berbeda. Pada puisi "I, Too" dan "Incident" terdapat karakteristik hibriditas yang berbeda. Pada puisi "I, Too", tokoh "aku" pada awalnya terlihat menegaskan hegemoni penguasa tetapi pada akhir puisi ternyata menunjukkan sikap perlawanan. Terlihat tunduk pada hegemoni penguasa merupakan bentuk dari hibriditas terkooptasi. Pada puisi "I, Too", hibriditas terkooptasi tidaklah terlihat selalu buruk meskipun pihak tertindas seakan-akan menerima hegemoni penguasa.

I am the darker brother.

They send me to eat in the kitchen

But I laugh,

And eat well, 
And grow strong.

Tokoh "aku" mengakui dirinya sebagai masyarakat kulit hitam dan menerima perlakuan berbeda dari masyarakat kulit putih. Hal tersebut terlihat jelas pada kata-kata They send me to at in the kitchen. Tokoh "aku" yang berkulit hitam disuruh makan di dapur ketika tuan "kulit putih" datang. Hibriditas terkooptasi ditegaskan bahwa tokoh "aku" menerima perlakuan tersebut dengan lapang dada dan merasa baik-baik saja. Tokoh "aku" menerima hegemoni dan mengikuti kebijakan penguasa.

Di sisi lain, puisi "I, Too" memperlihatkan bentuk hibriditas organik yang mana tokoh "aku" memberikan sikap perlawanan untuk tidak terus berada dalam hegemoni penguasa.

\section{Tomorrow, \\ I'll be at the table \\ When company comes. \\ Nobody'll dare \\ Say to me, \\ "Eat in the kitchen,"}

Tokoh "aku" menyatakan bahwa dia tidak akan selalu di bawah hegemoni penguasa. Keyakinan diri si "aku" bahwa tidak akan yang berani menyuruhnya makan di dapur menunjukkan hibridasi organik. Masyarakat kulit hitam di dalam puisi "I, Too" merupakan kalangan rendah di bawah hegemoni masyarakat kulit putih.

Besides,

They'll see how beautiful I am

And be ashamed-

\section{I, Too, am America}

Perlawanan tokoh "aku" terus berlanjut dengan elegan. Kata-kata They'll see how beautiful I am, And be shamed membuktikan bahwa perlawanan atas dominasi pihak yang kuat tidak harus keras dan brutal. Menunjukkan kehebatan diri bisa menjadi perlawanan yang kuat dan efektif. Dengan begitu, pihak yang lemah akan diakui dan bisa lepas dari penindasan. Hal ini merupakan sesuatu hal yang luar biasa dilakukan oleh pihak yang tertindas untuk menghentikan dominasi pihak penguasa. Ini juga merupakan bentuk hibriditas antara budaya masyarakat kulit hitam sebagai pihak tertindas dan kulit putih sebagai pihak penguasa.

Selanjutnya, pada puisi "Incident", ada sedikit perbedaan bentuk hibriditas dibandingkan puisi "I, Too" . Puisi "Incident" sebenarnya memiliki pola yang sama dengan puisi "I, Too" yaitu terdapat hibriditas kooptasi dan oganik. Hibriditas terkooptasi terlihat pada awal puisi di mana tokoh "aku" merasa kondisi di tempat tinggalnya menyenangkan. Padahal, tempat tinggal tokoh "aku" berada di tengah-tengah dominasi masyarakat kulit putih.

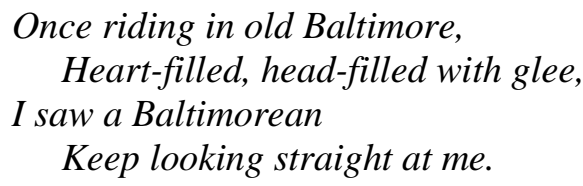


Pada rangkaian kata-kata di atas memperlihatkan tokoh "aku" menerima keadaan dirinya dengan baik meskipun tidak mendapatkan respon yang baik. Orang-orang di Baltimore memandang sinis tokoh "aku" dikarenakan perbedaan warna kulit. Tokoh "aku" dengan gambarannya merasakan kegembiraan yang luar biasa ketika berjalan di kota Baltimore seperti kata-kata Heart-filled, headflled with glee. Tokoh "aku" menerima sepenuhnya keadaan dan kondisi di Baltimore tanpa ada resistensi.

\author{
Now I was eight and very small, \\ And he was no whit bigger, \\ And so I smiled, but he poked out \\ His tongue, and called me, "Nigger." \\ I saw the whole of Baltimore \\ From May until December: \\ Of all the things that happened there \\ That's all that I remember
}

Untaian kata-kata di atas menegaskan bentuk hibriditas terkooptasi. Meskipun tokoh "aku" diintimidasi dengan kata yang menghina seorang warga kulit hitam dengan kata Nigger, tokoh "aku" tidak melakukan perlawanan. Tetapi, tokoh "aku" sudah berusaha bersikap sopan tetapi yang didapatkan adalah perlakuan rasis atas perbedaan warna kulit. Kemudian, kata-kata I saw the whole of Baltimore......that's all that I remember, memperlihatkan pasrah dengan kondisi yang diterima. Sesungguhnya perlakuan yang diterima tokoh "aku" tidak bisa dibenarkan karena itu melanggar hak hidup seorang manusia. Apalagi, seseorang yang menjadi korban adalah seorang anak kecil berumur delapan tahun.

Selanjutnya, hibriditas organik atau perlawanan tidak begitu jelas terlihat. Bukannya tidak ada resistensi sama sekali, tetapi tidak sejelas kata-kata pada puisi “I, Too”. Hibriditas organik atau resistensi terhadap dominasi penguasa terlihat pada sikap acuh dan abai terhadap perlakuan rasis kepada tokoh "aku". Hal itu merupakan kekuatan mental yang luar biasa untuk seorang anak berusia delapan tahun. Meskipun tokoh "aku" dilecehkan dengan panggilan Nigger, tokoh "aku" tidak membalas langsung perlakuan pihak yang menghinanya. Tokoh "aku" hanya mengabaikan dan mengingat apa yang sudah ia alami di Baltimore. Hal ini seakan-akan dijadikan sebuah pengingat untuk perjuangan melawan dominasi pihak yang mendominasi di masa depan. Kemungkinan lainnya bahwa tokoh "aku" memberikan gambaran bagaimana perlakuan rasis adalah hal yang biasa terjadi meskipun terjadi secara vulgar di tengah publik

\title{
4 Simpulan
}

Tujuan dari penelitian ini adalah mengeksplorasi unsur puisi, kajian poskolonial dan hibriditas pada puisi "I, Too" karya Langston Hughes dan "Incident" karya Countee Cullen. Hasilnya ditemukan data berupa diksi, persamaan bunyi, oposisi biner antara kulit hitam dan kulit putih, dan hibriditas organic dan terkooptasi. Permasalahan utama pada puisi "I, Too" dan "Incident" adalah hibriditas dan oposisi biner kulit hitam dan kulit putih. Tokoh "aku" pada kedua puisi "I, Too" dan "Incident" mengungkapkan dengan suasana dan perasaan kulit hitam yang didominasi oleh kulit putih.

Hibriditas terkooptasi dan organik memperlihatkan bagaimana seorang warga kulit hitam bersikap terhadap dominasi masyarakat kulit putih. Di satu sisi, seorang kulit hitam menerima perlakuan buruk dari masyarakat kulit putih, tetapi di sisi lain adalah sikap perlawanan. Masyarakat 
kulit hitam dianggap sebagai budak pekerja dan masyarakat kulit putih sebagai tuan. Para budak dianggap pekerja yang harus mengikuti "tuan" tanpa ada perlawanan. Puisi "I, Too" dan "Incident" menunjukkan sebuah budaya baru di kalangan masyarakat kulit hitam bahwa masyarakat kulit hitam tidak dilahirkan untuk diperlakukan sebagai budak tanpa perlawanan. Budaya baru tersebut merupakan hibriditas yang terdapat pada puisi "I, Too" dan "Incident" .

\section{Referensi}

Aljazeera. (2020). In 2020, the Black Lives Matter movement shook the world.

Aminuddin. (2004). Pengantar Apresiasi Karya Sastra. Sinar Baru Algesindo.

Bhabha, H. K. (2007). The location of culture. Routledge.

Black Lives Matter. (2021). Black Lives Matter.

Brown, J. (2011). The Hibridity of History in Midnight's Children. Sigma Teu Delta Review: A National Undergraduate Literary Journal, 5.

Furqon, S. \& B. (2020). Hibriditas poskolonialisme Homi K. Bhabha dalam Novel Midnight's Children Karya Salman Rusdie. UIN Sunan Gunung Jati.

Jumiati. (2016). Gaya bahasa dan citraan dalam kumpulan puisi senyawa karya Andrei Aksana. Basra, 1 No. 1.

Kosasih, E. (2008). Khazanah Sastra Melayu Klasik. Nobel Edumedia.

Martono, N. (2014). Sosiologi perubahan sosial: perspektif klasik, modern, postmodern, dan poskolinial. PT Raja Grafindo.

Nazir, M. (1988). Metodologi Penelitian. Ghalia Indonesia.

Olivia, H. M., \& Salim, M. N. (2020). Mimikri Dalam Puisi Hari Itu Aku Akan Bersiul Karya Wiji Thukul (Kajian Poskolonial). Universitas Sebelas Maret, 2-4.

Pradopo, R. D. (2007). Pengkajian puisi. Gadjah Mada University Press.

Semi, A. (2012). Metode Penelitian Sastra. Angkasa Bandung.

Semiawan, C. (2010). Metode Penelitian Kualitatif. PT Grasindo.

Sendari, A. (2019). Mengenal Jenis Penelitian Deskriptif Kualitatif pada Sebuah Tulisan Ilmiah.

Suswandari, Meidawati., \& H. K. T. (2018). Ontologi Puisi. CV. Intishar Publishing.

Syuropati, M. A. (2012). 7 teori sastra kontemporer \& 17 tokohnya. IN AzNa Books.

Teeuw, A. (2010). Sastra dan ilmu sastra: pengantar teori sastra. Dunia Pusat Jaya. 